\title{
Production and Immunological Characterization of a Monoclonal Antibody to Trichophyton quinckeanum: Interaction with Phosphorylcholine-bearing Components
}

\author{
By RAQUEL A. CALDERON* AND GRAHAM I. SHENNAN \\ Department of Medical Microbiology, Medical Mycology and Tropical Dermatology Unit, \\ London School of Hygiene and Tropical Medicine, Keppel Street (Gower Street), \\ London WCIE 7HT, UK
}

(Received 26 February 1987; revised 28 April 1987)

\begin{abstract}
A monoclonal antibody (Tq-1) that interacts with the phosphorylcholine (PC)-bearing antigens of Trichophyton quinckeanum was produced by fusion of myeloma cells (JKAg-8) with spleen cells of BALB/c mice immunized with an alum-precipitated fraction of $T$. quinckeanum cytoplasmic antigen. It was characterized as an IgM class antibody by immunodiffusion using anti-Ig heavy chain specific reagents, ELISA using immunoglobulin-specific peroxidaseconjugated antibodies, and by gel filtration chromatography; it showed high affinity for Staphylococcus aureus protein-A. Interaction of Tq-1 with PC-like antigens of $T$. quinckeanum was demonstrated by inhibition studies using ELISA, immunoblotting, immunoprecipitation and immuno electron microscopy techniques. The binding activity of Tq-1 antibody with a range of dermatophyte proteins was completely inhibited by prior incubation with PC hapten. Moreover, dermatophyte antigens reacting with the monoclonal antibody reacted strongly with sera from chronically infected mice. Dermatophyte antigens derived from both young $(24 \mathrm{~h})$ and old ( $20 \mathrm{~d}$ ) cultures reacted with Tq-1 and this binding was inhibited by PC, suggesting that Tq-1 target antigen PC appears at an early stage during fungal growth and remains throughout its life.
\end{abstract}

\section{INTRODUCTION}

Dermatophytes are fungi which cause infections of skin, hair and nails in humans and animals. Antigenic heterogeneity and cross reactivity are characteristic of dermatophyte species (Schechter et al., 1966; Andrieu et al., 1968; Philpot, 1978). In a study of the dermatophyte species Trichophyton rubrum, Trichophyton mentagrophytes, Microsporum canis and Epidermophyton floccosum, by crossed immunoelectrophoresis, up to 35 different antigenic components were demonstrated, from which up to 20 components were shared between species (Svejgaard, 1985). Analyses of dermatophyte antigens have revealed three main components: (1) nitrogenfree polysaccharides (Bishop et al., 1965); (2) glycoproteins (Barker et al., 1962); and (3) keratinases (Grappel \& Blank, 1972). These antigens have been shown to participate preferentially in immediate and/or delayed type hypersensitivity in sensitized humans and guinea pigs (Barker et al., 1962; Ito, 1965; Grappel \& Blank, 1972). Natural and experimental infections in humans and animals confer immunity to reinfection with certain fungal species (Jones et al., 1974; Grappel et al., 1974). This immunity is cell-mediated, and T-cells appear to play a major role (Green et al., 1983; Calderon \& Hay, 1984a, b). Thus, the presence of fungal antigens that elicit protective immunity in dermatophytosis may be inferred. Equally, dermatophyte antigens that interfere with specific immune functions have been reported (Walters et al., 1974). In a previous study we found that immunity in mice experimentally

\footnotetext{
Abbreviations: PC, phosphorylcholine; CA, cytoplasmic antigen; CFA, culture filtrate antigen; SA, surface antigen.
} 
infected with Trichophyton quinckeanum was significantly reduced by injection of an alumprecipitated fraction of fungal cytoplasmic antigen (CA) (Calderon \& Hay, 1984b). In view of the heterogeneity of dermatophyte antigens, the production of monospecific antibodies is a logical step in the isolation and characterization of antigenic components.

Here we report the production of a monoclonal antibody $(\mathrm{Tq}-1)$ to an alum-precipitated fraction of $T$. quinckeanum $\mathrm{CA}$ and present an immunochemical study of $T$. quinckeanum $\mathrm{CAs}$, culture filtrate antigens (CFAs) and surface antigens (SAs), using the monoclonal antibody and sera from immune and infected mice.

\section{METHODS}

Dermatophyte antigen preparation. Antigens were prepared from Trichophyton quinckeanum (NCPF 309) obtained from the National Collection of Pathogenic Fungi, Mycology Reference Laboratory, PHLS Colindale, London, and described by Calderon \& Hay $(1984 a)$. A single spore suspension $\left(6 \times 10^{9}\right)$ of $T$. quinckeanum (Calderon \& Shennan, 1987) was inoculated in 31 of neutral glucose peptone (NGP) broth containing $2 \%(\mathrm{w} / \mathrm{v})$ glucose, $1 \%(\mathrm{w} / \mathrm{v})$ peptone and $0.25 \%(\mathrm{w} / \mathrm{v})$ sodium $\beta$-glycerophosphate. The stirred culture was incubated at $28{ }^{\circ} \mathrm{C}$ for a week. A sample $(500 \mathrm{ml})$ of culture was taken daily for $7 \mathrm{~d}$ and replaced by fresh broth. Individual samples were filtered through a nylon mesh and the mycelium retained. The filtrate was centrifuged at $20000 \mathrm{~g}$, concentrated with polyethylene glycol (PEG) and dialysed against 0.15 M-phosphate-buffered saline (PBS; $0.145 \mathrm{M}$-sodium chloride, $0.15 \mathrm{M}$-sodium phosphate $\mathrm{pH} 7 \cdot 2$ ) to yield CFA.

The retained mycelial mat was resuspended in PBS and disrupted in a Dyno-Mill cell disintegrator (KDL). Cell rupture was accomplished in $3 \mathrm{~min}$ at a specimen flow of $10 \mathrm{~m} \mathrm{~s}^{-1}$. The suspension was centrifuged at $20000 \mathrm{~g}$ and the supernatant, referred to as CA, was concentrated with PEG and dialysed against PBS.

The SAs from a $3 \mathrm{~d}$ culture were extracted with detergent. Mycelium was resuspended in $10 \mathrm{mM}$ - Tris/ $\mathrm{HCl}$ buffer $\mathrm{pH} 8.3$ containing $1 \%(\mathrm{w} / \mathrm{v})$ sodium deoxycholate and protease inhibitors - $250 \mathrm{~mm}$-EDTA, $6.8 \mathrm{mM}-\mathrm{N}$ - $\alpha-\mathrm{p}$-tosyllysine-chloromethyl ketone (TLCK), $100 \mathrm{mM}$-phenylmethylsulphonyl fluoride (PMSF) and $5 \mathrm{mM}$-pepstatin - and incubated overnight at $4{ }^{\circ} \mathrm{C}$. The suspension was centrifuged at $10000 \mathrm{~g}$ for $30 \mathrm{~min}$ at $4{ }^{\circ} \mathrm{C}$ and the supernatant was dialysed and concentrated in an Amicon concentrator in PBS. The molecular mass cut-off of the filter was $15 \mathrm{kDa}$. This sample is referred to as SA.

The protein content of these preparations was estimated by the Coomassie blue $\mathrm{G}$ method (Read \& Northcote, 1981 ), using bovine serum albumin (BSA) as standard. Samples were stored at $-20^{\circ} \mathrm{C}$. Except when specified, $\mathrm{CA}$ and CFA fractions used throughout this work were derived from a $5 \mathrm{~d}$ culture.

Mouse immunization. For production of monoclonal antibodies, male BALB/c mice, 6-12 weeks old (obtained from the National Institute for Medical Research, London), were injected twice intraperitoneally at a 1 month interval with CA (150 $\mathrm{g}$ protein) adsorbed onto alum (Hudson \& Hay, 1976). Six weeks after the second injection mice were injected intravenously with CA (10 $\mu \mathrm{g}$ protein) in PBS. Mice were killed $5 \mathrm{~d}$ later and their spleens excised.

For production of antiserum a similar scheme of immunization was followed, except that the CA was given in Freund's complete adjuvant ( $1: 1)$ (Difco); mice were bled $10 \mathrm{~d}$ after the booster injection and serum was separated by centrifugation.

Chronic infection in mice. Mice were infected as reported by Calderon \& Hay (1984a); the method was modified by the use of a heavy inoculum of mycelium from a $2 \%$ malt-agar plate containing approximately $10^{8}-10^{9}$ spores to induce chronicity. All mice developed a dermatophyte infection by day 7 , with $25-40 \%$ of mice developing a spontaneous chronic infection (present for at least 8 weeks), whereas the remainder healed spontaneously within 2 weeks. Chronically infected mice were bled 8 weeks after infection.

Production of mouse monoclonal antibodies. The fusion of immune spleen cells with mouse myeloma cells was by a modification of the method of Fazekas de St Groth \& Scheidegger (1980). Spleen cells $\left(5 \times 10^{7}\right)$ were mixed with $5 \times 10^{7} \mathrm{BALB} / \mathrm{c}$ myeloma cells P3X63Ag8653 (JKAg-8) and fused by using $0.5 \mathrm{ml}(50 \%$, w/v) polyethylene glycol 4000 (Merck) containing $25 \mu \mathrm{l}$ dimethyl sulphoxide (Sigma). The JKAg-8 myeloma cells were provided by Dr D. B. Thomas (National Institute for Medical Research, London). Fused cells were grown in HAT-RPMI 1640 medium. Supernatants were tested for antibody activity by ELISA (see below) and positive hybrids were cloned by limiting dilution. The antibody class was determined by three methods: (i) by ELISA using peroxidase-conjugated rabbit anti-mouse IgM (Miles) or affinity purified goat anti-mouse IgG (Sigma); (ii) by double diffusion in agar using a commercially available kit with anti- $\operatorname{Ig}(\operatorname{IgG} 1, \operatorname{IgG} 2 a, \operatorname{IgG} 2 b, \operatorname{IgG} 3, \operatorname{IgM}$ and $\operatorname{IgA})$ heavy-chain-specific reagents (Serotec); and (iii) by Sephadex G-200 exclusion (Whitaker, 1963) using 0.2\% (w/v) Blue Dextran 2000 (Pharmacia) for void volume determination.

Protein-A affinity purification. Samples (200-500 ml; approx. 15-20 $\mu \mathrm{g} \mathrm{IgM}$ antibody $\mathrm{ml}^{-1}$ ) of myeloma cell culture supernatant were loaded onto a $5 \mathrm{ml}$ prewashed Sepharose 4B-protein-A column [Pharmacia, with binding capacity of $100-125 \mathrm{mg}$ antibody $\left.(5 \mathrm{ml})^{-1}\right]$. The unbound fraction was eluted with PBS. The affinity 
bound fraction was eluted with $0 \cdot 2 \mathrm{M}$-glycine $/ \mathrm{HCl}$ buffer, $\mathrm{pH} 2 \cdot 2$, and collected in tubes containing $0 \cdot 6 \mathrm{M}-\mathrm{Tris} / \mathrm{HCl}$ buffer, pH 8.2. The peak was pooled and dialysed against PBS. The protein yield was calculated from the $A_{280}$, using a value of absorbance of 1.4 for a $1 \mathrm{mg} \mathrm{m}^{-1}$ solution. Samples were stored at $-70^{\circ} \mathrm{C}$. In some experiments Tq-1 was pretreated with $10 \mathrm{~nm}$-cytidine $5^{\prime}$-diphosphocholine (Sigma) for $1 \mathrm{~h}$ at $37^{\circ} \mathrm{C}$.

ELISA. Reactivity of monoclonal antibodies to T. quinckeanum antigens and to PC was tested by a modification of the ELISA of Wilson \& Hearn (1983). Briefly, microtitre plates (Linbro, Flow Laboratories) were coated with $100 \mu \mathrm{l}$ of CA at $10 \mu \mathrm{g} \mathrm{ml}^{-1}, \mathrm{CFA}$ at $10 \mu \mathrm{g} \mathrm{ml}^{-1}$ or BSA-PC at $1 \mu \mathrm{g} \mathrm{ml}^{-1}$ in $0.06 \mathrm{M}$-bicarbonate buffer $\mathrm{pH} 9.6$, and incubated overnight at room temperature. Cytidine 5'-diphosphocholine conjugated to BSA (BSA-PC) by the method of Péry et al. (1979) was a gift from Dr R. M. Maizels (Imperial College, London). Briefly, 50 mg cytidine $5^{\prime}$-diphosphocholine was oxidized for $20 \mathrm{~min}$ in $2.5 \mathrm{ml} \mathrm{l} \mathrm{M}-\mathrm{NaIO}_{4}$ and residual $\mathrm{IO}_{4}^{-}$was inactivated by $0.15 \mathrm{ml} 1 \mathrm{M}$ ethylene glycol. The activated cytidine $5^{\prime}$-diphosphocholine was mixed under stirring with $140 \mathrm{mg}$ BSA in $5 \mathrm{ml}$ $0.01 \mathrm{M}$-sodium carbonate buffer $\mathrm{pH} 9.6$. The $\mathrm{pH}$ of the reaction mixture was maintained constant for $1 \mathrm{~h}$ at $20^{\circ} \mathrm{C}$ by addition of $5 \%$ sodium carbonate. The reaction mixture was reduced overnight with $5 \mathrm{ml} 0 \cdot 2 \mathrm{M}-\mathrm{NaBH}_{4}$ and the $\mathrm{pH}$ of the resulting solution adjusted to $\mathrm{pH} 3.5$ with $1 \mathrm{M}$-formic acid for $1 \mathrm{~h}$. After neutralization with $1 \mathrm{M}-\mathrm{NH}_{4} \mathrm{OH}$ the protein solution was dialysed against PBS. Microtitre plates were washed three times with PBS containing $0.05 \%$ Tween 20 , pretreated with $1 \%$ (w/v) BSA for 30 min and incubated with $100 \mu \mathrm{l}\left(10,2 \cdot 5,0 \cdot 6\right.$ or $\left.0 \cdot 15 \mu \mathrm{g} \mathrm{ml}^{-1}\right)$ monoclonal antibody for $2 \mathrm{~h}$. Plates were again washed as before and $100 \mu \mathrm{l}$ affinity-purified peroxidaseconjugated sheep anti-mouse IgG $(1: 350$, Sigma), or goat anti-mouse $\operatorname{IgM}(1: 200$, Sigma) were added to each well and incubated for a further $2 \mathrm{~h}$ at room temperature and washed. The substrate $(0.07 \mathrm{M}$-sodium citrate buffer pH 5.0 with $10 \mathrm{mg} o$-phenylenediamine and $10 \mu 1 \mathrm{H}_{2} \mathrm{O}_{2}(30 \%, \mathrm{w} / \mathrm{v})$ per $100 \mathrm{ml}$ solution $(100 \mu 1$ per well $)$ was added to each well; the plates were then incubated in the dark at room temperature for $30 \mathrm{~min}$ before the reaction was stopped with $1 \mathrm{M}-\mathrm{H}_{2} \mathrm{SO}_{4}\left(100 \mu \mathrm{l}\right.$ per well). The $A_{490}$ was recorded in a Dynatech Microplate Reader MR 600 (Dynatech) using the antigen and conjugated reagents as controls.

$S D S-P A G E$. This was done by an adaptation of the method of Laemmli (1970). Samples of CA, CFA and SA were dissolved in SDS-PAGE sample buffer $(0.0625 \mathrm{M}$-Tris $/ \mathrm{HCl} \mathrm{pH} 6.8$, containing $2 \%(\mathrm{w} / \mathrm{v}) \mathrm{SDS}, 10 \%(\mathrm{v} / \mathrm{v})$ glycerol, $5 \%(\mathrm{v} / \mathrm{v}) 2$-mercaptoethanol and $0 \cdot 0002 \%(\mathrm{w} / \mathrm{v})$ bromophenol blue) to give a protein concentration of $1 \mathrm{mg} \mathrm{ml}{ }^{-1}$. Samples were heated at $100{ }^{\circ} \mathrm{C}$ for $2 \mathrm{~min}$ just before application to the gel. Slab gels of $5-15 \%$ gradient acrylamide with a $10 \mathrm{~mm} \mathrm{4 \%}$ (w/v) stacking gel were run in a slab gel electrophoretic apparatus (Bio-Rad). Buffers were as described by Laemmli (1970).

Samples were electrophoresed at a constant voltage of $50 \mathrm{~V}$ for approximately $15 \mathrm{~h}$, and gels stained with Coomassie brilliant blue R-250. Low molecular mass markers [phosphorylase $b, 94 \mathrm{kDa} ; \mathrm{BSA}, 67 \mathrm{kDa}$; ovalbumin, $43 \mathrm{kDa}$; carbonic anhydrase, $30 \mathrm{kDa}$; soybean trypsin inhibitor, $20 \mathrm{kDa}$; and $\alpha$-lactalbumin, $14.4 \mathrm{kDa}$, Pharmacia], were run alongside the fungal antigens.

Immunoblotting from polyacrylamide gels. The proteins in the gel were transferred to nitrocellulose (NC) sheets (Bio-Rad) in a Trans-Blot cell (Bio-Rad) as described by Towbin et al. (1979). After electrophoresis at $60 \mathrm{~V}$ and $0.25 \mathrm{~A}$ for $6 \mathrm{~h}$ the NC sheets were cut into separate strips and the efficacy of the transfer was assessed by staining one of the strips with amido black. The strip with the molecular mass markers was also stained. Other strips were incubated overnight with $2 \%(\mathrm{w} / \mathrm{v})$ casein in PBS-Tween containing $0.05 \%$ sodium azide at $4{ }^{\circ} \mathrm{C}$. The NC strips were incubated with either a $1: 100$ dilution of mouse antisera (immune or infected), or with monoclonal antibody (neat supernatant or protein-A purified) for $2 \mathrm{~h}$ at room temperature. The strips were then washed three times with sodium azide-free PBS-Tween and incubated with a $1: 1000$ dilution of peroxidase-conjugated rabbit anti-mouse IgM (Dako Patts) in PBS-Tween for a further $2 \mathrm{~h}$. Strips were washed as before and incubated with the substrate -

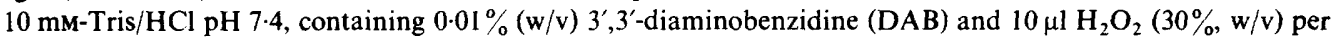
$100 \mathrm{ml}$ - for $30 \mathrm{~min}$, and washed in tap water followed by distilled water.

Radioiodination. T. quinckeanum antigens (CA and CFA) and molecular mass markers were labelled with [125I]iodide (Amersham) in the presence of Iodo-gen (1,3,4,6-tetrachloro-3 $\alpha, 6 \alpha$-diphenylglycoluril, Pierce) as described by Markwell \& Fox (1978). Briefly, $100 \mu \mathrm{g}$ lodo-gen in $100 \mu \mathrm{l}$ chloroform were placed in an Eppendorf tube and the chloroform was evaporated with a nitrogen jet. The protein $(10 \mu \mathrm{g}$ in $50 \mu \mathrm{l}$ PBS $)$ was transferred to the tubes containing adsorbed Iodo-gen and mixed with $200 \mu \mathrm{Ci}(0.74 \mathrm{MBq})$ of [ ${ }^{125}$ I]iodide. The mixture was incubated for $10 \mathrm{~min}$ at room temperature. The reaction was stopped by addition of $5 \mu \mathrm{l}$ of a saturated solution of tyrosine and the mixture passed through a Sephadex G-25 column to remove free iodine. The peak with high TCA precipitability index (over $85 \%$ ) was pooled and stored at $-20{ }^{\circ} \mathrm{C}$. These labelled preparations were used in the immunoprecipitation assay.

Radioimmunoprecipitation. Soluble radioactive fungal CAs or CFAs $\left(10^{4}-10^{5}\right.$ c.p.m. $)$ were incubated with sera $(5-10 \mu \mathrm{l})$ from mice immunized with $\mathrm{CA}$, or chronically infected with $T$. quinckeanum, or with monoclonal antibody $(10 \mu \mathrm{g}$ of purified antibody or $50 \mu \mathrm{l}$ of neat supernatant). Antigen-antibody complexes were precipitated with a suspension $(50 \mu \mathrm{l})$ of formalin-fixed Staphylococcus aureus (BRL) and washed twice by centrifugation with PBS $/ 0.5 \%$ Triton X-100 at $4{ }^{\circ} \mathrm{C}$. The pellet was suspended in SDS-PAGE sample buffer and subjected to PAGE as before. After electrophoresis the gel slabs were fixed (7.5\% acetic acid, $25 \%$ methanol in distilled water) and dried 


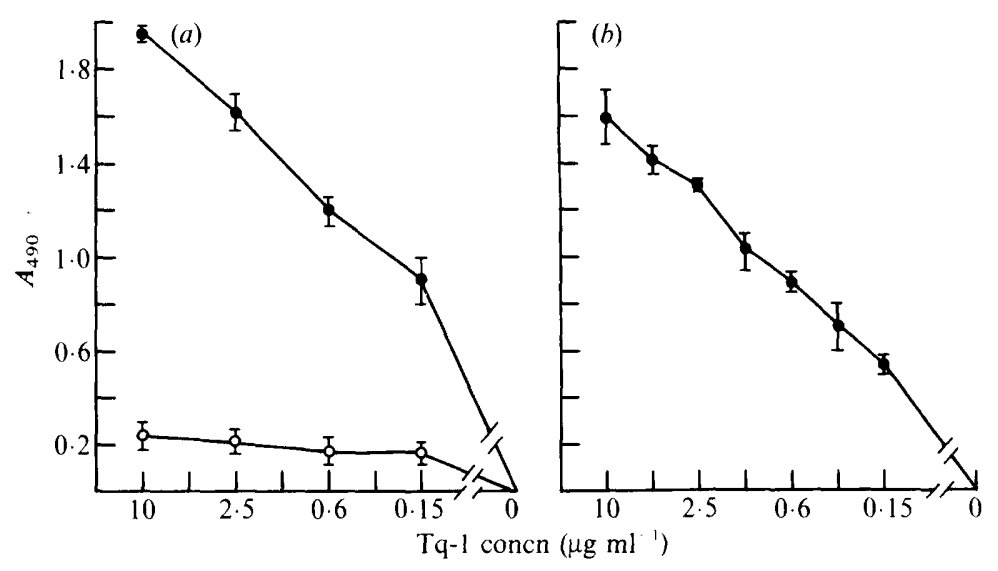

Fig. 1. Binding activity of monoclonal antibody Tq-1 to T. quinckeanum CAs $(a)$ and PC $(b)$ measured by ELISA. (a) Microtitre plates were coated with T. quinckeanum CAs $\left(10 \mu \mathrm{g}\right.$ protein $\left.\mathrm{ml}^{-1}\right)$. Reactions were measured with peroxidase-conjugated goat anti-mouse $\operatorname{IgM}(\bullet)$, or sheep anti-mouse $\operatorname{IgG}(O)$ antibodies, with $o$-phenylenediamine substrate. $(b)$ Microtitre plates were coated with BSA-PC $\left(1 \mu \mathrm{g} \mathrm{ml}^{-1}\right)$ and the reaction was measured with peroxidase-conjugated goat anti-mouse IgM.

in a gel drier (Bio-Rad 1125B). Radiolabel was detected by autoradiography using a Kodak (X-omat) intensifying screen held at $-70^{\circ} \mathrm{C}$.

Immuno electron microscopy. The binding of monoclonal antibody to T. quinckeanum spores was demonstrated by an immunogold labelling technique described by Garzon et al. (1982). T. quinckeanum spores, germinated for $18 \mathrm{~h}$ in NGP broth, were fixed in 0.5\% glutaraldehyde in PBS. Protein-A-purified Tq-1 antibody (50 $\left.\mu \mathrm{g} \mathrm{ml}^{-1}\right)$ was used together with protein-A-gold particles ( $15 \mathrm{~nm}$, Janssen Pharmaceutica). Samples were stained with $0.5 \%$ uranyl acetate and lead citrate (Reynolds, 1963). Sections were examined in an AE1 EM 801 electron microscope.

\section{RESULTS}

\section{Monoclonal antibody reactive to $P C$-bearing antigens in $T$. quinckeanum}

Hybridomas were obtained from the fusion of myeloma cells (JKAg-8) with spleen cells from a mouse immunized with an alum-adsorbed fraction of $T$. quinckeanum CAs. Supernatants from three microtitre plates were screened for antibody reactivity to CA by ELISA. Ten positive clones were obtained and subcloned by limiting dilution on macrophage feeder layers. All clones showed strong binding to protein-A; all reacted with affinity-purified peroxidase-conjugated goat anti-mouse IgM, but not with sheep anti-mouse IgG in ELISA. IgM class specificity was confirmed by using anti-Ig heavy-chain specific reagents in immunodiffusion, and by Sephadex G-200 exclusion.

These monoclonal antibodies revealed similar specificities to fungal antigens as judged by both immunoblotting and immunoprecipitation. This uniformity in reactivity may be explained by a preferential adsorption of certain antigens onto alum. One antibody-producing clone was selected for detailed analysis; the monoclonal antibody is subsequently referred to as Tq-1. Fig. $1(a)$ shows the reactivity of this antibody with anti-IgM, but not with anti-IgG, in ELISA.

Interaction of Tq-1 antibody with PC hapten was assessed by ELISA using PC-BSA. Tq-1 antibody, purified through a Sepharose protein-A affinity column, showed high reactivity to $\mathrm{PC}$; at a concentration of $150 \mathrm{ng} \mathrm{ml}^{-1} \mathrm{Tq}-1$ still showed significant reactivity (Fig. $1 b$ ). This reactivity was inhibited by prior incubation of Tq-1 with $\mathrm{PC}(10 \mathrm{nM})$ for $1 \mathrm{~h}$ at $37^{\circ} \mathrm{C}$. Supernatant from control hybridomas derived from the same cell fusion, but not reactive to CA, did not react with PC; background $A_{490}$ values of $0.08-0.12$ were obtained.

\section{Binding of Tq-1 with $C A$ and $C F A$ fractions and inhibition with $P C$}

The reactivity of $\mathrm{Tq}-1$ with antigens of young and old cultures of $T$. quinckeanum was determined by ELISA. CAs and CFAs were obtained daily for $7 \mathrm{~d}$ as described in Methods. The 


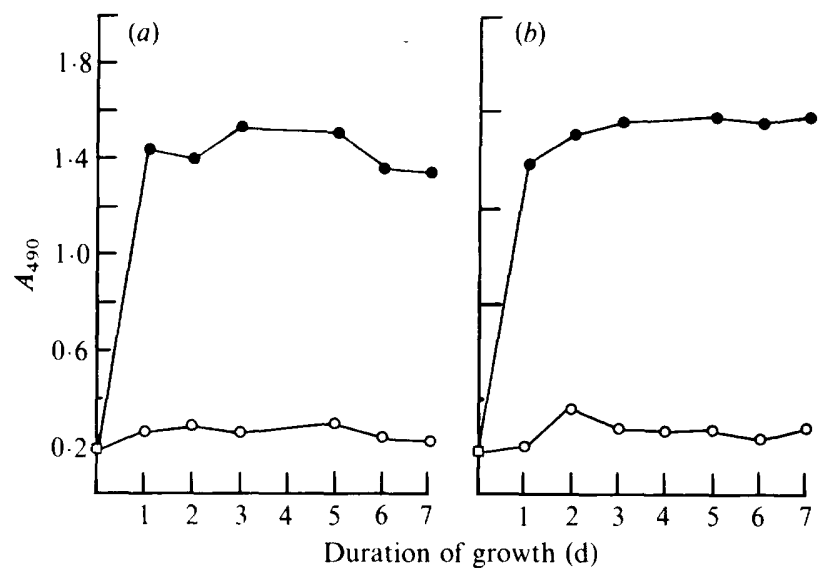

Fig. 2. Inhibition of monoclonal antibody Tq- 1 binding in ELISA to CAs $(a)$ and CFAs $(b)$ with PC. Microtitre plates were coated with CA, or CFA at $10 \mu \mathrm{g}$ protein $\mathrm{ml}^{-1}$ obtained from 1 to $7 \mathrm{~d}$ cultures, and incubated with Tq-1 (๑) at $1 \mu \mathrm{g} \mathrm{ml}^{-1}$ or Tq-1 pretreated with $10 \mathrm{nM}-\mathrm{PC}(\mathrm{O})$ at $1 \mu \mathrm{g} \mathrm{ml}^{-1}$. Reaction was measured with peroxidase-conjugated goat anti-mouse IgM.

monoclonal antibody $\left(1 \mu \mathrm{g} \mathrm{ml}^{-1}\right)$ was incubated in a microtitre plate sensitized with each fungal antigenic fraction $\left(10 \mu \mathrm{g}\right.$ protein $\left.\mathrm{ml}^{-1}\right)$ followed by incubation with peroxidase-conjugated goat anti-mouse IgM and substrate. CAs and CFAs from 1 to $7 \mathrm{~d}$ cultures showed similar reactivity to Tq-1 antibody (Fig. 2). This reactivity, however, was completely inhibited by prior incubation of Tq-1 antibody with PC (Fig. 2). Antigens from a $20 \mathrm{~d}$ culture were also tested; their reactivity to $\mathrm{Tq}-1$, and their inhibition by $\mathrm{PC}$ was comparable to that observed in 1 to $7 \mathrm{~d}$ cultures. This finding suggests that Tq-1 target antigens appear at a very early stage during fungal growth and remain constant throughout fungal life. Furthermore, these components displayed PC-like determinants.

\section{Complexity of T. quinckeanum antigens}

The antigenic complexity of $T$. quinckeanum was revealed by analysis of CAs, CFAs and SAs by SDS-PAGE (5-15\% gradient acrylamide). Under reducing conditions, over 20 bands were detected both for the CAs and for the SAs and over 15 bands were detected for the CFAs. The apparent molecular masses of the bands ranged from 10 to over $100 \mathrm{kDa}$. At least 10 bands of the same molecular mass were common to the three antigenic fractions analysed.

\section{Identification of $T$. quinckeanum antigens recognized by immune and infected sera and by Tq-1 antibody}

The binding of mouse sera from immune or chronically infected mice, and of Tq-1 antibody, was examined on immunoblots of CA, CFA and SA fractions separated under reducing conditions by SDS-PAGE (5-15\% gradient acrylamide). Molecular masses were estimated from blots of low molecular mass markers, run together with fungal antigens and stained with amido black. Reaction of a pool of sera from mice immunized with the CA fraction in Freund's complete adjuvant identified at least $25 \mathrm{CA}$ bands with molecular masses ranging from $14 \mathrm{kDa}$ to over $100 \mathrm{kDa}$, with a prominent band of approximately $67 \mathrm{kDa}$ (Fig. $3 a, b$, lane 1). Mice bearing a chronic infection reacted against $\mathrm{CA}$ in a similar manner to immunized mice (Fig. $3 a$, lane 2). Here, at least 12 bands were found to coincide with those revealed by the immune sera. Binding of CA to Tq-1 produced at least six bands with molecular masses ranging from $35 \mathrm{kDa}$ to over $100 \mathrm{kDa}$; corresponding bands of these components were found in sera of immune and infected mice. Furthermore, pretreatment of Tq-1 antibody with $\mathrm{PC}$ hapten inhibited its reactivity to CA (Fig. $3 a$, lane 4 ).

Immune and chronic sera and $\mathrm{Tq}-1$ antibody reacted to the CFA fraction with fewer antigenic bands (Fig. 3b, lanes 1, 2 and 3). A prominent band of $67 \mathrm{kDa}$ was apparent with immune and 


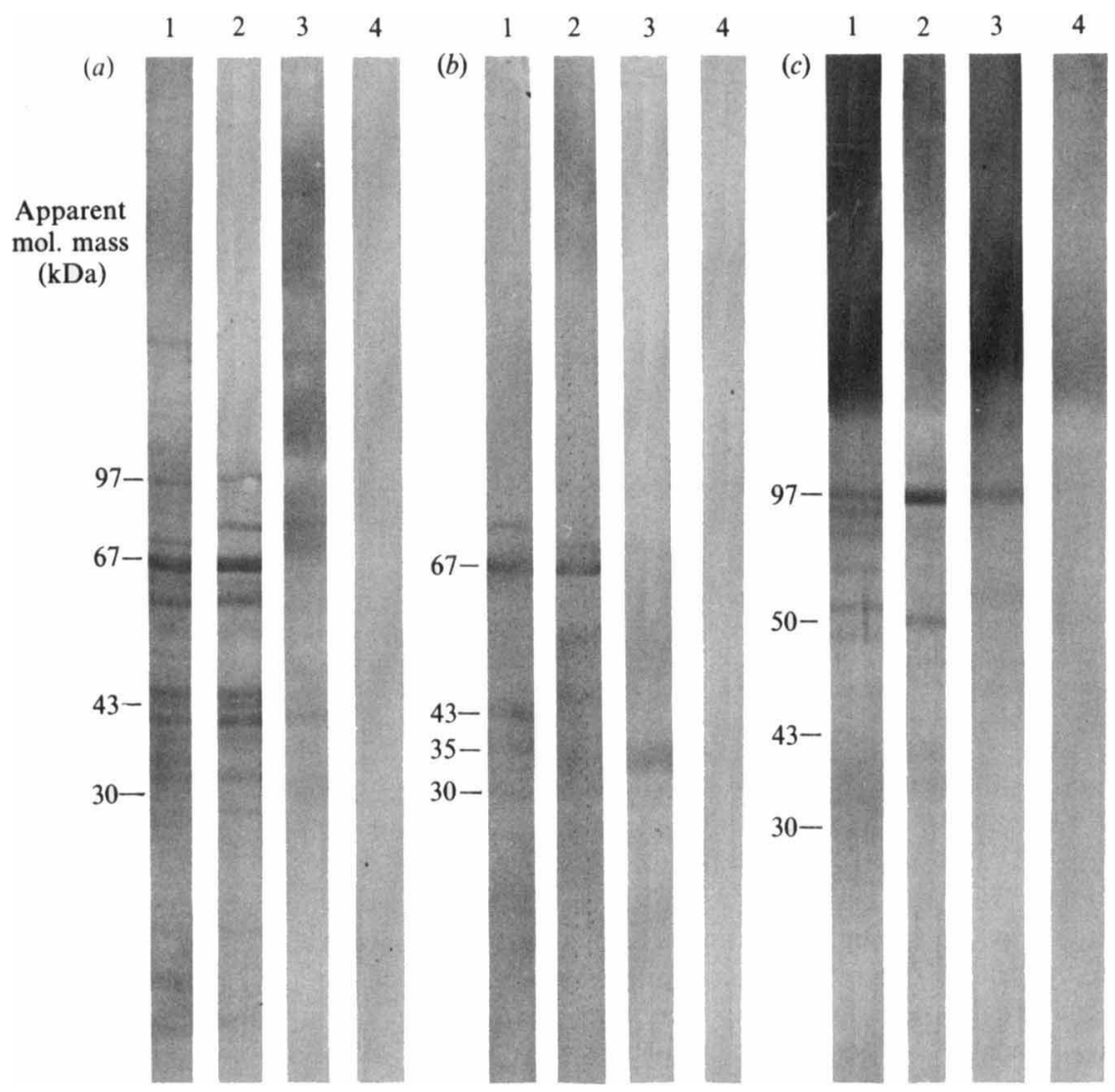

Fig. 3. $T$. quinckeanum cytoplasmic $(a)$, culture filtrate $(b)$ and surface $(c)$ components recognized by sera of immune and infected mice, and monoclonal antibody $\mathrm{Tq}-1$ using immunoblots. Antigens were separated under reducing conditions by SDS-PAGE (5-15\% gradient acrylamide) and transferred to nitrocellulose sheets. Blots were incubated for $2 \mathrm{~h}$ at room temperature with sera of immune (lane 1) or chronically infected (lane 2) mice, or with Tq-1 before (lane 3) or after (lane 4) treatment with PC. Reaction was revealed with rabbit anti-mouse IgM antibody with $3^{\prime}, 3^{\prime}$-diaminobenzidine substrate.

infected antisera. A component of approximately $35 \mathrm{kDa}$ present with Tq-1 (Fig. $3 b$, lane 3 ) was also reactive with both immune and chronic sera (Fig. $3 b$, lanes 1 and 2). Once again treatment of Tq-1 with PC removed this binding (Fig. $3 b$, lane 4).

Binding activity to SAs extracted with deoxycholate is shown in Fig. $3(\mathrm{c})$. Immune mouse sera bound at least seven components (Fig. $3 c$, lane 1) and of these, two bands of approximately $50 \mathrm{kDa}$ and $97 \mathrm{kDa}$ were present with serum from chronically infected animals (Fig. $3 c$, lane 2); Tq-1 antibody reacted with the $97 \mathrm{kDa}$ protein (Fig. 3c, lane 3). The reactivity of this SA component with PC-like antigenic components was confirmed by its removal after pretreatment of Tq-1 with PC (Fig. 3c, lane 4). Neither normal mouse sera, nor supernatants from control hybridomas, reacted with any dermatophyte antigenic fractions.

\section{Immunoprecipitation}

To analyse further the reactivity of immune and infected mouse sera and of $\mathrm{Tq}-1$ antibody to $T$. quinckeanum antigens, the antibody samples were combined with ${ }^{125} \mathrm{I}$-labelled CA or CFA fractions and then immunoprecipitated using formalin-fixed $S$. aureus and the precipitates analysed under reducing conditions by SDS-PAGE (5-15\% acrylamide gradient). The autoradiograph in Fig. 4 shows the results of such experiments. The immune sera precipitated eight different moieties of the CA fraction that migrated as proteins with apparent molecular 


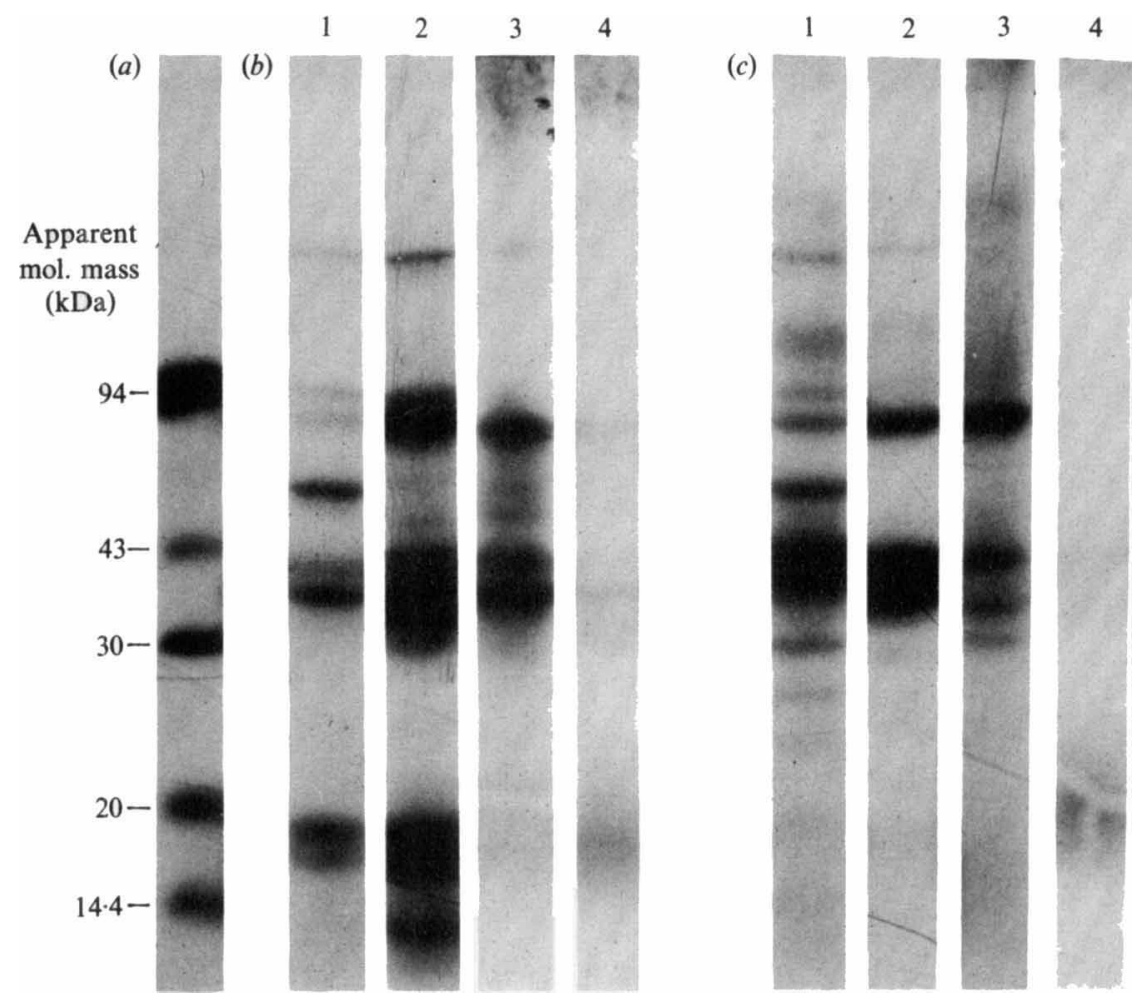

Fig. 4. Immunoprecipitation of cytoplasmic and culture filtrate components by mouse specific antibody and Tq-1 antibody. Radioiodinated CAs or CFAs were reacted with sera of immune (lane 1) or chronically infected (lane 2) mice, or with $\mathrm{Tq}_{\mathrm{q}-1}$ before (lane 3) or after (lane 4) treatment with PC. Samples were immunoprecipitated with formalin-fixed $S$. aureus, washed and resolubilized in SDSPAGE sample buffer under reducing conditions. (a) Molecular mass markers (see Methods); (b) CAs; (c) CFAs

masses of $15,20,35,40,50,65,67$ and one above $100 \mathrm{kDa}$ respectively (Fig. $4 b$, lane 1). Reactivity of the chronic infected sera was more pronounced, as indicated by the broad bands in the autoradiograph (Fig. $4 b$, lane 2), with three additional bands (12, 30 and $45 \mathrm{kDa})$ to those observed with immune sera. The monoclonal antibody $\mathrm{Tq}-1$ showed a better resolution when analysed against $\mathrm{CA}$ by immunoprecipitation, than by immunoblotting (Fig. 3). Six components of molecular mass $35,40,45,50,65$ and $>100 \mathrm{kDa}$ were precipitated with Tq-1 antibody (Fig. $4 b$, lane 3). Sera from immune and chronically infected mice and $\mathrm{Tq}-1$ antibody were also precipitated with the CFA fraction (Fig. 4c, lanes 1, 2, 3 and 4). Cross reactivity between components of CA and CFA fractions was evident in this study. The majority of CFA bands, precipitated with the various antibody fractions, were equivalent to bands of the CA fraction. Moreover, reactivity of Tq-1 with both CAs and CFAs was removed by prior incubation with PC (Fig. 4b, $c$, lane 4).

\section{Immuno electron microscopy}

Sections of T. quinckeanum spores germinated for $18 \mathrm{~h}$ in NGP broth were used, embedded and polymerized in gelatin capsules and incubated with Tq-1 antibody $\left(20 \mu \mathrm{g} \mathrm{ml}^{-1}\right)$ alone or pretreated with PC, followed by treatment with protein-A adsorbed to colloidal gold particles. Fig. 5(a) shows numerous gold particles on the cytoplasm of the spore reacting with the monoclonal antibody, and only a few scattered gold particles on the surface membrane of the spore can be seen. Pretreatment of Tq-1 with PC resulted in inhibition of this reaction (Fig. $5 b$ ). 

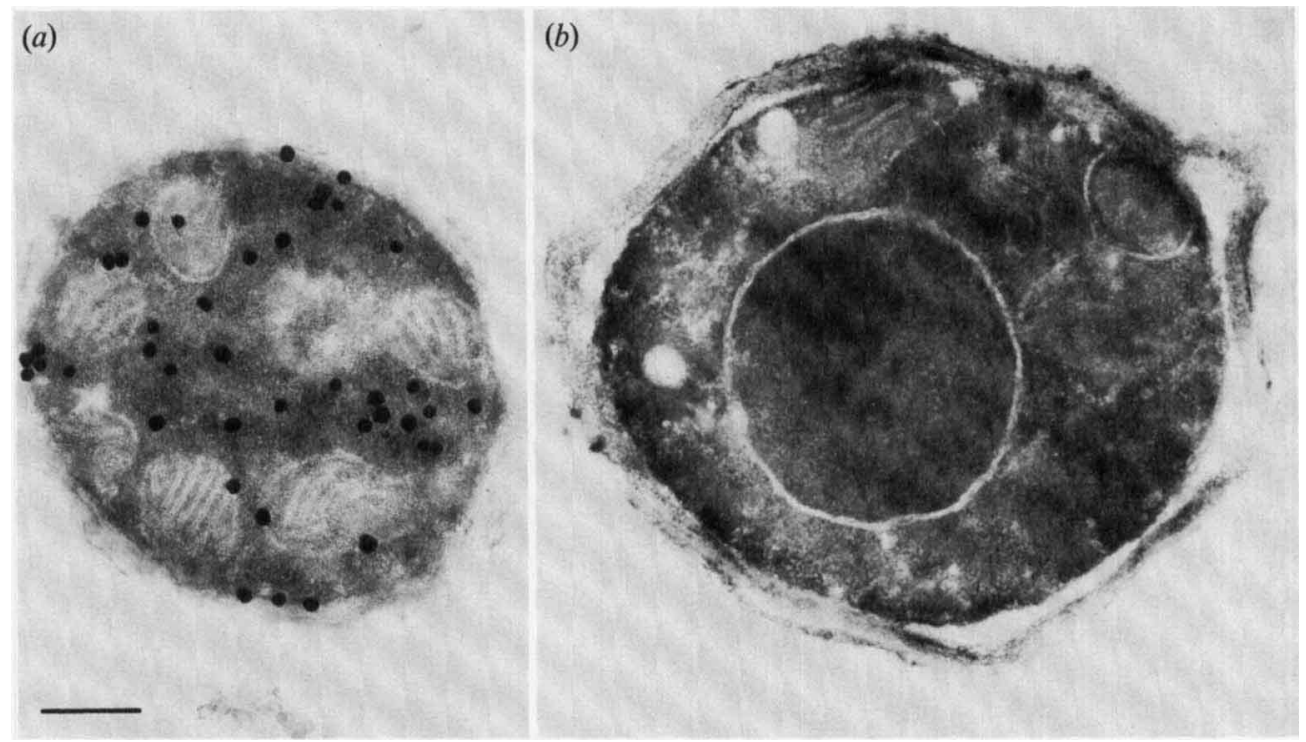

Fig. 5. Binding of $\mathrm{Tq}-1$ to $T$. quinckeanum spores using electron microscopy immunogold labelling. Glutaraldehyde-fixed germinated spores ( $18 \mathrm{~h}$ in NGP broth) were reacted with Tq-1 antibody. Binding was revealed with protein-A-gold-labelled particles and uranyl acetate/lead citrate. $(a)$ Tq-1; (b) $\mathrm{Tq}-1$ pretreated with PC. Bar, $0 \cdot 3 \mu \mathrm{m}$.

\section{DISCUSSION}

The present study concerns the production of a monoclonal antibody to an alum-precipitated fraction of $T$. quinckeanum CA. This fraction was chosen because it increases the susceptibility of BALB/c mice to dermatophyte infection, and appears to interfere with T-cell mediated immunity (Calderon \& Hay, 1984b).

Fusion of spleen cells from immune BALB/c mice with myeloma (JKAg-8) cells yielded ten positive clones with similar reactivity to $T$. quinckeanum $C A s$ as judged by immunoblotting and immunoprecipitation studies. The similarity amongst the clones may be explained by preferential precipitation of certain dermatophyte antigens with alum, which is known to precipitate protein molecules (Whitehouse, 1971). The monoclonal antibody described here and referred to as Tq-1 ( $T$. quinckeanum) antibody, was characterized as an IgM immunoglobulin by three criteria: (1) using specific anti-Ig-heavy chain reagents in immunodiffusion; (2) by affinity purified peroxidase conjugates in ELISA (Fig. $1 a$ ); and (3) by Sephadex G-200 exclusion. This IgM antibody showed an unexpected high affinity binding to protein-A of S. aureus, reported to interact mainly with IgG class immunoglobulins (Lindmark et al., 1983). However, some IgM polyclonal antibodies (Seppala et al., 1981) and IgM monoclonal antibodies (R. M. Maizel, personal communication) bind protein-A.

T. quinckeanum, in common with most species of dermatophytes (Andrieu et al., 1968), consists of a complex of antigens when analysed by PAGE. Since many determinants in the three antigenic fractions were shared, it was not surprising to find that Tq-1 antibody raised against CAs cross-reacted with CFAs and SAs (Figs 3 and 4).

Immunochemical studies of Tq-1 antibody and sera from immune and chronically infected mice were done by immunoblotting and immunoprecipitation analyses. Sera from immune and from infected mice showed more reactivity to CAs than to CFAs or SAs (Fig. 3). Most of the CAs reactive with immunized mice sera appeared to be also immunogenic during the prolonged course of a dermatophyte infection (Figs 3 and 4). Furthermore, the immunoprecipitation autoradiograph revealed that the cytoplasmic and culture filtrate determinants reactive with the Tq-1 antibody were highly immunogenic during infection (Fig. 4). SAs were the least immunogenic during the infection, and only one component was reactive with Tq-1 monoclonal 
antibody (Fig. 3). However, for a conclusive result SAs not released with deoxycholate should be examined.

Although specific antibodies are present during dermatophyte infections in humans and animals (Grappel et al., 1974), a protective role has not yet been found.

One of the significant findings in this study is the reactivity of $\mathrm{Tq}-1$ monoclonal antibody with PC-bearing antigens on the fungus, and the immunogenicity of this determinant during infection. PC is a widely distributed hapten that reacts with $\mathrm{C}$-reactive protein - an acute phase protein which appears in serum during certain infections, inflammatory conditions and tissue damage (Anderson \& McCarty, 1950). PC-like determinants have been found in bacteria (Brundish \& Baddiley, 1968), parasites (Pery et al., 1974) and in fungi such as the dermatophytes E. floccosum and T. mentagrophytes as well as Aspergillus fumigatus (Pepys \& Longbottom, 1971). The PC-like component of $E$. floccosum and $A$. fumigatus has been shown to contain carbohydrate (galactomannan), protein, choline and phosphate (Baldo et al., 1977). Here, the presence of $\mathrm{PC}$ hapten in T. quinckeanum has been demonstrated by inhibition studies. The interaction of Tq-1 monoclonal antibody with PC was shown in ELISA using PC conjugated to BSA (Fig. $1 b$ ), and by complete inhibition of binding to CAs and CFAs with PC (Fig. $2 a, b$ ). This inhibition was observed with antigenic fractions derived from both young $(24 \mathrm{~h})$ and old (7-20 d) cultures.

These results clearly indicate that $\mathrm{Tq}-1$ recognizes antigenic components containing the PC hapten, and that this hapten appears in the early stages of fungal growth and seems to remain throughout the life of the fungus. Longbottom \& Pepys (1964) reported that PC-like antigens were of somatic origin, detectable in mycelium of any age but only released from old cultures. Detection of this determinant in young cultures, in the present study, may be attributed to the use of a high affinity monoclonal antibody. Further confirmation that Tq-1 reacts with protein antigens that contain PC components came from inhibition studies using immunoblotting, immunoprecipitation and gold labelling techniques. Binding of $\mathrm{Tq}-1$ to determinants of various molecular masses in CA, CFA and SA fractions was completely inhibited by pretreatment of antibody with PC hapten (Figs 3 and 4), suggesting that the hapten PC is present in more than one molecule in the complex of fungal antigens. In hapten-carrier systems the antibody response may be directed against the hapten, the protein carrier or the hapten-carrier molecule (Mitchison, 1971). It seems that Tq-1 is directed either to the hapten (PC-like epitope) or the hapten-carrier molecule since binding was completely inhibited in the presence of PC.

Immunogold electron microscopy was carried out with $T$. quinckeanum spores and Tq-1 antibody. Protein-A-gold-labelled particles were observed mainly in the cytoplasm, with only a small proportion in the surface membrane (Fig. 5a). This finding correlates with results obtained by immunoblotting where surface antigen showed poor reactivity (Fig. 3).

In conclusion, the biological role of PC components in dermatophytes is unknown. However, it may be pertinent to the discussion that in other systems it has been demonstrated that PC coupled to the hapten-carrier DNP-Ficoll inhibits the anti-DNP immune response (Mitchell \& Lewers, 1976). It is possible that a similar phenomenon involving PC-bearing antigens occurs in dermatophyte infections.

This work was supported by a grant from the Medical Research Council of Great Britain. We thank Dr D. B. Thomas (National Institute for Medical Research, London) for providing the myeloma cell line (JKAg-8) and for helpful advice in setting up the monoclonal work. We are also grateful to Dr R. M. Maizels (Imperial College, London) for BSA-PC conjugate and Dr B. S. Drasar (London School of Hygiene and Tropical Medicine) for helpful advice.

\section{REFERENCES}

Anderson, H. C. \& MCCARTY, M. (1950). Determination of C-reactive protein in blood as measure of activity of disease process in acute rheumatic fever. American Journal of Medicine 8, 445-455.

Andrieu, S., Biquet, J. \& LalouX, B. (1968). Analyse immunoélectrophorétique comparée des structures antigénique de 17 espèces de dermatophytes. $\mathrm{Myco}$ pathologia et mycologia applicata 34, 161-185.
Baldo, B. A., Fletcher, T. C. \& Pepys, J. (1977). Isolation of a peptido polysaccharide from the dermatophyte Epidermophyton floccosum and a study of its reaction with human C-reactive protein and a mouse anti-phosphorylcholine myeloma serum. Immunology 32, 831-841.

Barker, S. A., Cruickshank, C. N. D., Morris, J. H. \& WoOD, S. R. (1962). The isolation of trichophytin 
glycopeptide and its structure in relation to immediate and delayed reactions. Immunology 5, 627-632.

Bishop, C. T., Perry, M. B., Blank, F. \& CoOper, F. P. (1965). The water soluble polysaccharides of dermatophytes. Canadian Journal of Chemistry 43, 30-39.

BRUNDish, D. E. \& BadDiley, J. (1968). Pneumococcal C-substance, a ribitol teichoic acid containing choline phosphate. Biochemical Journal 110, 573-582.

Calderon, R. A. \& HaY, R. J. (1984a). Cell-mediated immunity in experimental murine dermatophytosis. I. Temporal aspects of T-suppressor activity caused by Trichophyton quinckeanum. Immunology 53, 457464.

Calderon, R. A. \& Hay, R. J. (1984b). Cell-mediated immunity in experimental murine dermatophytosis. II. Adoptive transfer of immunity to dermatophyte infection by lymphoid cells from donors with acute or chronic infections. Immunology 53, 465-472.

Calderon, R. A. \& Shennan, G. I. (1987). Susceptibility of Trichophyton quinckeanum and Trichophyton rubrum to products of oxidative metabolism. Immunology 61, 283-288.

FazeKas de St GRoth, S. \& Scheidegger, D. (1980). Production of monoclonal antibodies: strategy and tactics. Journal of Immunological Methods 35, 1-21.

Garzon, S., Bendayan, M. \& Kurstak, E. (1982). Ultrastructural localization of viral antigen using protein-A-gold technique. Journal of Virological Methods 5, 67-73.

GRAPPEL, S. F. \& BLANK, F. (1972). Role of keratinases in dermatophytosis. I. Immune response of guinea pigs infected with Trichophyton mentagrophytes and guinea pigs immunized with keratinases. Dermatologica 145, 245-255.

Grappel, S. F., Bishop, C. T. \& Blank, F. (1974). Immunology of dermatophytes and dermatophytosis. Bacteriological Reviews 38, 222-250.

Green, F., Weber, J. K. \& Balish, E. (1983). The thymus dependency of acquired resistance to Trichophyton mentagrophytes dermatophytosis in rats. Journal of Investigative Dermatology 81, 31-38.

Hudson, L. \& HAY, F. C. (1976). Practical Immunology, 2nd edn. p.9. London: Blackwell.

Iro, Y. (1965). On the immunologically active substances of the dermatophytes. Journal of Investigative Dermatology 45, 275-284.

Jones, H. E., Reinhardt, J. H. \& Rinaldi, M. G. (1974). Acquired immunity to dermatophytes. $\mathrm{Ar}$ chives of Dermatology 109, 840-848.

LAEMMLI, U. K. (1970). Cleavage of structural proteins during the assembly of the head of bacteriophage T4. Nature, London 227, 680-685.

Lindmark, R., Thoren-Tolling, K. \& SJoquist, J. (1983). Binding of immunoglobulins to protein $A$ and immunoglobulin levels in mammalian sera. Journal of Immunological Methods 62, 1-13.

Longbottom, J. L. \& Pepys, J. (1964). Pulmonary aspergillosis: diagnostic and immunological significance of antigens and C-substance in Aspergillus fumigatus. Journal of Pathology and Bacteriology 88, 141-151.

Markwell, M. A. \& Fox, C. F. (1978). Surface specific iodination of membrane proteins of viruses and eucaryotic cells using 1,3,4,6-tetrachloro-3 $\alpha, 6 \alpha-$ diphenylglycoluril. Biochemistry 17, 4807-4817.
Mitchell, G. F. \& Lewers, H. M. (1976). Studies on immune responses to parasite antigens in mice. IV. Inhibition of an anti-DNP antibody response with the antigen, DNP-Ficoll containing phosphorylcholine. International Archives of Allergy and Applied Immunology 52, 235-240.

Mitchison, N. A. (1971). The carrier effect in the secondary response to hapten-protein conjugates. European Journal of Immunology 1, 10-18.

PePYs, J. \& Longbottom, J. L. (1971). Antigenic and C-substance activities of related glycopeptides from fungal, parasitic and vegetable sources. International Archives of Allergy and Applied Immunology 41, 219221.

Pery, P., Petit, A., Poulain, J. \& Luffau, G. (1974). Phosphorylcholine components in homogenates of nematodes. European Journal of Immunology 4, 637639.

Pery, P., Luffau, G., Charley, J., Petit, A., Rouze, P. \& Bernard, S. (1979). Cytidine-5'-diphosphocholine conjugates. Annals of Immunology 130, 517529.

PHILPOT, C. M. (1978). Serological differences among the dermatophytes. Sabouraudia 16, 247-256.

REYNOLDS, E. (1963). The use of lead citrate at high pH as an electron opaque stain in electron microscopy. Journal of Cell Biology 17, 208-212.

READ, S. M. \& NoRTHCOTE, D. H. (1981). Minimization in the response to different proteins of the Coomassie blue $\mathrm{G}$ dye-binding assay of protein. Analytical Biochemistry 116, 53-64.

Schechter, Y., LandaU, J. W., Dabrowa, N. \& NewCOMER, V. D. (1966). Comparative disc electrophoretic studies of proteins from dermatophytes. Sabouraudia 5, 144-149.

Seppala, I., Sarvas, H., Peterfy, F. \& Makela, O. (1981). The four classes of Ig can be isolated from mouse serum by using protein-A-Sepharose. Scandinavian Journal of Immunology 14, 335-342.

SVEJGAARD, E. (1985). Immunologic investigations of dermatophytes and dermatophytosis. Seminars in Dermatology 4, 201-221.

Towbin, H., Staehelin, T. \& Gordon, J. (1979). Electrophoretic transfer of proteins from polyacrylamide gels to nitrocellulose sheets: procedure and some applications. Proceedings of the National Academy of Sciences of the United States of America 76, 4350-4354.

Walters, B. A., ChICK, J. E. D. \& Halliday, W. J. (1974). Cell-mediated immunity and serum blocking factors in patients with chronic dermatophyte infections. International Archives of Allergy and Applied Immunology 46, 849-857.

WILSON, E. V. \& HEARN, V. M. (1983). Use of Aspergillus fumigatus mycelial antigen in enzymelinked immunosorbent assay and counter immunoelectrophoresis. Journal of Medical Microbiology 16, 97-105.

WHITAKER, J, R. (1963). Determination of molecular weights of proteins by gel filtration on Sephadex. Analytical Chemistry 35, 1950-1953.

WhITEHOUSE, M. W. (1971). The chemical nature of adjuvants. In Immunochemistry: an Advanced Textbook, pp. 571-601. Edited by L. E. Glynn \& M. W. Steward. London, UK: John Wiley. 